Scholarship Repository

University of Minnesota Law School

Articles

Faculty Scholarship

2020

Eminent Domain Law as Climate Policy

Alexandra Klass

University of Minnesota Law School, aklass@umn.edu

Follow this and additional works at: https://scholarship.law.umn.edu/faculty_articles

Part of the Law Commons

Recommended Citation

Alexandra Klass, Eminent Domain Law as Climate Policy, 2020 WIS. L. REV. 49 (2020), available at https://scholarship.law.umn.edu/faculty_articles/670.

This Article is brought to you for free and open access by the University of Minnesota Law School. It has been accepted for inclusion in the Faculty Scholarship collection by an authorized administrator of the Scholarship Repository. For more information, please contact lenzx009@umn.edu. 


\title{
EMINENT DOMAIN LAW AS CLIMATE POLICY
}

\author{
ALEXANDRA B. KLASS*
}

In 2019, several states adopted aggressive clean energy laws and other states are poised to do the same. These policies require electric utilities to secure all of the electricity they sell to customers from carbon-free energy resources by a specified date, and many also require the state to drastically reduce carbon emissions from the transportation sector, increase energy efficiency in buildings, and otherwise decarbonize their economies. In order to meet these mandates, states must transform the physical infrastructure used to create and transport energy. This will require building new power plants that run on carbon-free energy resources like wind, solar, hydropower, or nuclear energy; constructing the electric transmission lines and other infrastructure needed to deliver these energy resources to consumers; setting standards and mandates for new buildings, vehicles, and transportation infrastructure that will reduce carbon emissions; and providing direct funding, tax incentives, new permitting processes, and staff to support the public and private actors that will implement these changes. These needs are becoming well documented. What remains completely unexplored, however, is the potential for state property law reform - most notably eminent domain law- to limit the development of fossil fuels and promote the growth of alternative energy to support these new clean energy policies. This Article contends that states should consider eliminating eminent domain rights for fossil fuel projects and extending eminent domain rights for certain clean energy projects as part of their state climate policies. Moreover, each state's approach to eminent domain reform may differ based on the current energy mix in the state as well as the potential for technological development. These policy conversations regarding the use of eminent domain for energy projects are critical to developing robust state clean energy laws. They also can provide a useful template for Congress if, in the future, it decides to enact federal climate policy.

Introduction

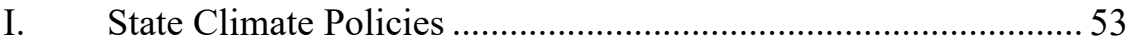

II. Use of Eminent Domain for Energy Development ......................57

A. State and Federal Eminent Domain Authority for Energy

Projects

B. Lawsuits Challenging the Use of Eminent Domain for

Energy Development

1. Federal Court Legal Challenges to New Natural Gas Pipelines

* Distinguished McKnight University Professor, University of Minnesota Law School. I received helpful comments on earlier drafts of this Article from Eric Biber, Sara Bronin, Peter Byrne, James Coleman, Nestor Davidson, Daniel Farber, Lisa Heinzerling, Sharon Jacobs, Tim Mulvaney, Richard Revesz, JB Ruhl, Christopher Serkin, Larry Shapiro, David Spence, Michael Vandenbergh, Shelley Welton, and Katrina Wyman. 
2. State Court Legal Challenges to New Oil and NGL Pipelines

3. Minimal Legislative Eminent Domain Reform for Energy Projects

III. Eminent Domain Law as Climate Policy................................... 71

A. The Limits of Current Eminent Domain Lawsuits and the Role of Legislative Reform........................................... 72

B. Evaluating Which Energy Projects Should be Subject to Reform

C. Process Issues: Creating Statutory Presumptions in Eminent Domain Law 80

D. Constitutional Questions and the Possibility of Federal Reform .82

Conclusion 83

\section{INTRODUCTION}

In 2019, state legislatures in Maine, Nevada, New Mexico, New York, and Washington joined California and Hawaii in adopting aggressive clean energy laws to phase out the use of fossil fuels to generate electricity by $2050 .{ }^{1}$ Although these laws are not all the same, they are the first to create mandates to completely eliminate greenhouse gas (GHG) emissions in the electricity sector and some of them impose mandates on energy use outside the electricity sector. These policies include rapidly ratcheting up the percentage of electricity sales that utilities must procure from renewable or carbon-free energy resources, reducing carbon emissions from the transportation sector, increasing energy efficiency in buildings, and the like. ${ }^{2}$

In order to meet these mandates, states must transform the physical infrastructure used to generate and transport energy. This transformation includes building new power plants that run on carbon-free energy resources like wind, solar, hydropower, or nuclear energy; constructing the electric transmission lines and other transport infrastructure needed to deliver these energy resources to consumers; setting standards and mandates for new buildings, vehicles, and transportation infrastructure that will reduce carbon emissions; developing new technologies like costeffective battery and other storage resources; and providing direct funding, financial incentives, new permitting processes, and staff to support the public and private actors that will implement these changes. These

1. See infra notes 5-8.

2. See infra notes 5-8. 
needs are becoming well documented. ${ }^{3}$ What remains completely unexplored, however, is the potential for state property law-most notably eminent domain law - to slow or halt the continued development of fossil fuel use as a part of these state clean energy laws. Currently, lawsuits by environmental groups and landowners constitute the primary tool used to block new fossil fuel infrastructure development that, at least in the short term, remains extremely profitable.

This Article contends that states should consider eminent domain reform as a component of state clean energy policy. Eminent domain law is important because it is a valuable incentive governments grant to the private sector to build energy-related projects. At the present time, many fossil fuel projects like oil and gas pipelines have eminent domain rights while many clean energy projects do not. Reforms can include eliminating existing eminent domain rights for fossil fuel projects like oil and gas pipelines and expanding eminent domain rights for projects that support clean energy development like interstate electric transmission lines. Doing so has the potential to further state climate policies as well as provide a template for Congress if, in the future, it enacts federal climate policy.

This dual approach to eminent domain is new. Generally, changes to eminent domain law move in only in one direction - to expand eminent rights to encourage economic development when such development is a policy priority or to reduce or eliminate eminent domain rights when such actions are viewed as an abuse of private property rights. By contrast, a dual approach to eminent domain law to support climate policy should explicitly recognize the role of eminent domain in the energy sector as an incentive to both build certain projects and to stop certain projects simultaneously.

This Article begins in Part I by exploring the newly enacted state clean energy laws, highlighting the focus in these laws on new carbonfree resource development coupled with the lack of focus on preventing new fossil fuel projects. Part II turns to eminent domain law and provides a brief history of the use of eminent domain to encourage or discourage energy development in the United States. Examples include the state delegation of eminent domain power to oil companies to build pipelines and to electric utilities to build electric transmission lines, Congressional delegation of nationwide eminent domain authority to interstate natural gas pipeline companies in the 1940s and to interstate oil pipelines for the duration of World War II, and recent controversies over oil and gas pipelines that have led to calls for eminent domain reform in some states. In each of these examples, state legislators and Congress have used eminent

3. See, e.g., Legal Pathways to Deep Decarbonization in the United STATES (Michael B. Gerrard \& John C. Dernbach eds., 2019). 
domain authority as a policy tool to either encourage or discourage the private sector from building targeted energy projects.

Part III evaluates the benefits and drawbacks of using eminent domain law as an affirmative component of state climate policy-both expanding it for clean energy projects and restricting or eliminating it for fossil fuel projects. It concludes that there are substantive and political benefits to coupling restrictions on eminent domain authority for fossil fuel projects with expansion of eminent domain authority for certain clean energy projects. Moreover, states or groups of states may have different approaches to this issue. For instance, it remains contested in many states whether there is a legitimate role for natural gas as a "bridge fuel" that may influence state law reforms for gas-related projects. Likewise, technological developments such as carbon capture and sequestration (CCS) and other techniques for minimizing carbon emissions from fossil fuel plants may also change the calculus. These policy conversations regarding the use of eminent domain for energy projects are critical to developing robust state clean energy laws. They also can provide a useful template for Congress if, in the future, it decides to enact aggressive nationwide carbon reduction policies. ${ }^{4}$ Such federal policies could, for example, limit or eliminate the nationwide eminent domain authority that exists today to build interstate natural gas pipelines or otherwise reconsider existing property incentives for fossil fuel and clean energy projects.

4. See America's Transportation Infrastructure Act of 2019, S. 2302, 116th Cong. § 1401 (2019), https://www.eenews.net/assets/2019/07/29/document_gw_04.pdf [https://perma.cc/WET2-2DW6] (\$287 billion bipartisan highway bill released by the Senate Environment and Public Works Committee with specific provisions for reducing GHG emissions from the transportation sector and improving climate resilience of highway projects); Maxine Joselow, \$287B Highway Bill Includes Climate Title for 1st Time Ever, E\&E NEws: GREENwIRE (July 29, 2019), https://www.eenews.net/greenwire/stories/1060806381 (reporting on highway bill); Catherine Morehouse, Senators Target 50\% National Renewable Energy Standard by 2035, Zero-Carbon by 2050, UTIL. DIVE (June 27, 2019), https:/www.utilitydive.com/news/senators-target-50-national-renewable-energystandard-by-2035-zero-carbon/557722/ [https://perma.cc/RWS2-DFRR] (discussing zerocarbon bill introduced in the U.S. Senate); Dean Scott, House Democrats Unveil Plan for 100\% Clean Energy by 2050, BlOOMBERG ENV'T (Jan. 8, 2020), https://news.bloombergenvironment.com/environment-and-energy/house-democratsunveil-plan-for-100-clean-energy-by-2050 (reporting on provisions of proposed "Climate Leadership and Environmental Action for Our Nation's Future," or "CLEAN Act"); Tiffany Stecker, Democrats Eye Plan to Cut Carbon Emissions with Existing Law, BLOOMBERG ENV'T (July 23, https://news.bloombergenvironment.com/environment-and-energy/democrat-eyes-planto-cut-carbon-emissions-with-existing-law. 


\section{STATE Climate Policies}

In 2019, state legislatures in Maine, Nevada, New Mexico, New York, and Washington joined California and Hawaii in adopting aggressive clean energy laws to phase out the use of fossil fuels to generate electricity by $2050 .{ }^{5}$ More states are likely to follow suit in future years. ${ }^{6}$ Some of these state laws also set economy-wide carbon reduction goals, which will require a complete transformation of how these states generate and use energy. For instance, in addition to the mandate on electric power producers to eliminate carbon emissions from the electricity they sell to consumers, the New York law requires the state to reduce statewide carbon emissions from all sources $85 \%$ below 1990 levels by 2050 , and offset the remaining $15 \%$ through other technologies to remove carbon from the atmosphere such as creating carbon sinks, engaging in reforestation, or developing other technologies. ${ }^{7}$ New Mexico im-

5. See S. 1679, 129th Leg., 1st Reg. Sess. (Me. 2019); S. 358, 2019 Leg., 80th Sess. (Nev. 2019); S. 489, 54th Leg., 1st Sess. (N.M. 2019); Assemb. 8429, 2019 Leg., 203rd Sess. (N.Y. 2019); S. 5116, 66th Leg., Reg. Sess. (Wash. 2019); S. 100, 2018 Leg., Reg. Sess. (Cal. 2018); H.R. 623, 28th Leg., Reg. Sess. (Haw. 2015); Morehouse, supra note 4 (summarizing state laws); Progress Toward 100\% Clean EnERgY, UCLA LUSKIN CENTER FOR INNOVATION (Nov. 2019), https://innovation.luskin.ucla.edu/wpcontent/uploads/2019/11/100-Clean-Energy-Progress-Report-UCLA-2.pdf [https://perma.cc/Q69T-QL5G] (summarizing state and local 100\% clean energy laws).

6. See, e.g., Iulia Gheorghiu, Virginia, Maryland Unveil 100\% Clean Energy Plans, but NGOs not Satisfied, UtiL. Dive (Dec. 20, 2019), https://www.utilitydive.com/news/virginia-maryland-unveil-100-clean-energy-plans-butngos-not-satisfied/569475/ [https://perma.cc/H63D-LVXU] (discussing proposed legislation in Virginia and Maryland); see also Matthew Bandyk, Virginia Approves 100\% Clean Energy Legislation, Pushing State Toward 2.4 GW Storage, RGGI, UTIL. Dive (updated Mar. 6, 2020, 9:00 AM), https:/www.utilitydive.com/news/virginia-cleanenergy-legislation-pushes-state-toward-storage-rggi/572349/ [https://perma.cc/ZE29LE3Q] (reporting on legislative enactment of the Virginia Clean Economy Act in 2020); H.B. 1526, 2020 Gen. Assemb., Reg. Sess. (Va. 2020), https://lis.virginia.gov/cgibin/legp604.exe?201+ful+HB1526ER [https://perma.cc/4PFQ-UVHF] (text of Virginia Clean Economy Act).

7. See Assemb. 8429, 2019 Leg., 203rd Sess. (N.Y. 2019); Michael Gerrard, The Heat is on, New York: A New Climate Law is a Major Landmark, but Now Requires Work and Sacrifice, N.Y. DAILY NEwS (June 23, 2019), https://www.nydailynews.com/opinion/ny-oped-start-innovating-new-york-20190623-

3mucksnuazak3axgpggpygxtly-story.html [https://perma.cc/3LD2-3CTX] (discussing significant changes to electricity sector, buildings, transportation, and jobs in the state to comply with the new law); Jesse McKinley \& Brad Plumer, New York to Approve One of the World's Most Ambitious Climate Plans, N.Y. Times (June 18, 2019), https://www.nytimes.com/2019/06/18/nyregion/greenhouse-gases-ny.html [https://perma.cc/YU68-HSGV]; Morehouse, supra note 4 (summarizing state laws); Brad Plumer, It's New York vs. California in a New Climate Race. Who Will Win?, N.Y. TimeS (July 8, 2019), https://www.nytimes.com/2019/07/08/climate/new-york-californiaclimate-race.html [https://perma.cc/3427-C3F8] (comparing New York and California climate laws and both states' implementation challenges). 
posed a requirement that electric utilities procure $80 \%$ of their electricity sales from renewable resources and $100 \%$ from carbon free resources by 2045, along with a commitment by Executive Order to reduce carbon emissions economy-wide by at least $45 \%$ below 2005 levels by $2030 .^{8}$

These new laws expand upon and differ in significant ways from state renewable portfolio standards (RPSs) that have been in place since the 1990s and now exist in twenty-nine states. ${ }^{9}$ First, RPSs - which require electric utilities to source a certain percentage of retail electricity sales from renewable energy resources by a certain date, such as $10 \%$ by 2025 or $50 \%$ by $2050^{10}$ - apply only in the electricity sector while many of the new clean energy policies apply to all segments of the economy that produce carbon emissions such as buildings and transportation. ${ }^{11}$ This distinction is important because the transportation sector now emits more GHGs nationwide than the electricity sector and the same is true in many states. ${ }^{12}$ Second, by focusing on energy that is "carbon free" or

8. See S. 489, 54th Leg., 1st Sess. (N.M. 2019); Catherine Morehouse, Three's Company: New Mexico Joins California, Hawaii in Approving 100\% Clean Energy Mandate, UTIL. Dive (Mar. 13, 2019), https://www.utilitydive.com/news/threescompany-new-mexico-joins-california-hawaii-in-approving-100-clea/550390/

[https://perma.cc/2YA2-WUGD]; Benjamin Storrow, N.M. Tries to Quit Coal. 'Change is Hard, E\&E News: Climatewire (Jan. 3, 2020), https://www.eenews.net/stories/1061977471 [https://perma.cc/DMJ9-EYH8] (discussing provisions of New Mexico's clean energy law).

9. For a discussion of state RPS laws, see State Renewable Portfolio Standards and Goals, NAT'L Conf. St. Legislatures (Dec. 31, 2019), http://www.ncsl.org/research/energy/renewable-portfolio-standards.aspx

[https://perma.cc/P77L-4FPH] (describing RPSs and summarizing laws in the states); Galen Barbose, Lawrence Berkeley Nat'l Lab., U.S. Renewables Portfolio STANDARDS: 2018 ANNUAL REPORT (2018), http://etapublications.lbl.gov/sites/default/files/2018_annual_rps_summary_report.pdf [https://perma.cc/97GH-A4NE]; Shelly Welton, Electricity Markets and the Social Project of Decarbonization, 118 Colum. L. REV. 1067, 1084-86 (2018) (discussing state RPSs).

10. See DSIRE, NC Clean Energy TeCh. Ctr., Renewable \& Clean Energy STANDARDS (June 2019), https://s3.amazonaws.com/ncsolarcen-prod/wpcontent/uploads/2019/07/RPS-CES-June2019.pdf [https://perma.cc/2GZQ-TRYF] (showing RPSs in all the states); Morehouse, supra note 4.

11. See Benjamin Storrow, N.Y. Enacted a Landmark Climate Law. Now Comes the Hard Part, E\&E News: Climatewire (July 29, 2019), https://www.eenews.net/climatewire/stories/1060802517 (discussing economy-wide scope of New York legislation and other states' laws).

12. Sources of Greenhouse Gas Emissions, EPA, https://www.epa.gov/ghgemissions/sources-greenhouse-gas-emissions

[https://perma.cc/E5M7-AUGR]; EPA, FAST FACTS: U.S. TRANSPORTATION SECTOR GREENHOUSE GAS EMISSIONS 1990-2017 (2019), https://www.epa.gov/sites/production/files/2019-06/documents/420f19047.pdf [https://perma.cc/Q265-2MW4] [hereinafter "FAST FACTS"]; Johannes Friedrich et al., 6 Charts to Understand State Greenhouse Gas Emissions, World RES. InST. (Aug. 10, 2017), https://www.wri.org/blog/2017/08/6-charts-understand-us-state-greenhouse-gas- 
"zero-emission" rather than "renewable," the new clean energy laws allow a larger number of technologies to be used, including nuclear energy and CCS technologies, thus making it more feasible to set a $100 \%$ mandate. ${ }^{13}$ By contrast, most RPS percentages in the states are more modest $-10 \%$ or $25 \%$ by a specified year. ${ }^{14}$ For example, in California, the mandate is $60 \%$ renewable electricity by 2030 and $100 \%$ carbon-free electricity by $2045 .{ }^{15}$ New Mexico, Nevada, and New York have similar distinctions between the requirements for renewable electricity and carbon-free electricity. ${ }^{16}$

These new laws stress the urgency of addressing climate change. For instance, the New York law contains detailed information on the adverse effects of climate change on the "economic well-being, public health, natural resources, and the environment of New York" that include rising sea levels, increased storms, declining fish populations, exacerbation of air pollution and disease, and the like. ${ }^{17}$ The law cites to international research reports concluding that "substantial reductions in greenhouse gas emissions will be required by mid-century in order to limit global warming to no more than $2{ }^{\circ} \mathrm{C}$ and ideally $1.5^{\circ} \mathrm{C}$, and thus minimize the risk of severe impacts from climate change." ${ }^{18}$ It goes on to state that:

emissions [https://perma.cc/4YJB-L4FN]; Brad Plumer, U.S. Carbon Emissions Surged in 2018 Even as Coal Plants Closed, N.Y. Times (Jan. 8, 2019), https://www.nytimes.com/2019/01/08/climate/greenhouse-gas-emissions-increase.html [https://perma.cc/4ZUN-CYZQ]; Mitigation of Climate Change, N.Y. DEP'T OF ENVTL. CONSERVATION, https://www.dec.ny.gov/energy/99223.html [https://perma.cc/ZW6EEXJX] (transportation is largest source of New York GHG emissions); CAL. AIR RES. BD., CAlifornia Greenhouse Gas Emissions Inventory for 2000-2016-By Sector AND ACTIVITY (2018), https://ww3.arb.ca.gov/cc/inventory/pubs/reports/2000_2016/ghg_inventory_sector_sum 2000-16.pdf [https://perma.cc/Q7NE-EL29] (transportation is California's largest source of GHG emissions, at $41 \%$, with industry at $23 \%$ and electricity at $16 \%$ ). Carbon emissions make up $97 \%$ of U.S. transportation sector GHG emissions. FAST FACTS, supra.

13. See, e.g., Peter Behr, Energy Transitions: 100\% Renewable Grid Could Cost Trillions, E\&E NEWS: ENERGYWIRE (July 1, 2019), https://www.eenews.net/energywire/2019/07/01/stories/1060678667 (discussing new report assessing high costs and technical difficulties of building a 100\% renewable energy power grid as compared to the much lower costs and greater technical feasibility of an $80 \%$ or $100 \%$ zero-carbon grid); KATHRYNE ClEARY ET AL., RES. FOR THE FUTURE, CleAn ENERgY StANDARDS 1 (2019), https://media.rff.org/documents/CleanEnergyIssue20Brief_2.pdf [https://perma.cc/MQ5H-BQQG] (discussing the difference between a renewable portfolio standard and a clean energy standard).

14. DSIRE, supra note 10.

15. Id.

16. Id.

17. Assemb. 8429, 2019 Leg., 203rd Sess. (N.Y. 2019).

18. Id. 
Action undertaken by New York to reduce greenhouse [gas] emissions will have an impact on global greenhouse gas emissions and the rate of climate change. In addition, such action will encourage other jurisdictions to implement complementary greenhouse gas reduction strategies and provide an example of how such strategies can be implemented. It will also advance the development of green technologies and sustainable practices within the private sector, which can have far-reaching impacts such as a reduction in the cost of renewable energy components, and the creation of jobs and tax revenues in New York. ${ }^{19}$

Likewise, the Washington law states:

The legislature finds that Washington must address the impacts of climate change by leading the transition to a clean energy economy. One way in which Washington must lead this transition is by transforming its energy supply, modernizing its electricity system, and ensuring that the benefits of this transition are broadly shared throughout the state. . . The transition to one hundred percent clean energy is underway, but must happen faster than our current policies can deliver. Absent significant and swift reductions in greenhouse gas emissions, climate change poses immediate significant threats to our economy, health, safety, and national security. ${ }^{20}$

The state clean energy laws, which now cover nearly twenty-five percent of the U.S. population, provide for new commissions and councils to create scoping plans, rules, and other implementation mechanisms to shape the state's energy transition and assist regulated parties in meeting the new mandates. ${ }^{21}$ Thus, like RPSs, the laws are future looking-

19. Id.

20. S. 5116, 66th Leg., Reg. Sess. (Wash. 2019).

21. See, e.g., Assemb. 8429, 2019 Leg., 203rd Sess. (N.Y. 2019) (creating a Climate Action Council, an Environmental Justice Advisory Group, a Climate Justice Working Group, and a Just Transitions Working Group); S. 489, 54th Leg., 1st Sess., at 40-47, 50-51 (N.M. 2019) (creating "Energy Transition Economic Development Assistance Fund," "Energy Transition Indian Affairs Fund," "Energy Transition Displaced Worker Assistance Fund," and apprenticeship programs for construction of new energy generation facilities); S. 5116, 66th Leg., Reg. Sess., at 30-31, 50-51 (Wash. 2019) (creating stakeholder groups; requiring adoption of rules to promote energy transition; requiring Washington State Department of Commerce to "convene an energy and climate policy advisory committee to develop recommendations to the legislature for the coordination of existing resources, or the establishment of new ones, for the purposes of examining the costs and benefits of energy-related policies, programs, functions, activities, and incentives on an ongoing basis and conducting other energy-related studies and 
designed to create a vision for a new, carbon-free energy landscape to prevent or mitigate the harms associated with climate change. However, none of these laws have any provisions for limiting the construction of new fossil fuel energy projects through property law or using property law to encourage the construction of new clean energy projects. Instead, the premise of the laws is that if the state imposes new mandates and incentives for renewable and carbon-free energy, the economy will necessarily shift away from fossil fuels, desired projects will be built, and undesired projects will not be built. While that is perhaps most feasible in the electricity sector-where states can impose mandates on a small number of electricity providers and fairly easily track compliance-it will be far more difficult in other sectors of the economy, such as transportation, home heating, and industry. Moreover, many fossil fuel projects, such as new oil pipelines and natural gas projects, remain extremely lucrative. As a result, another complementary approach is for states to use property doctrine to place barriers in the way of new fossil fuel projects and to pave the way for new clean energy projects.

One of the primary ways the energy industry builds projects is through the power of eminent domain, which allows private actors to take private property for projects such as oil pipelines, natural gas pipelines, electric transmission lines, and the like under state law in some cases and federal law in others. The next Part discusses eminent domain authority in the energy sector as well as contemporary judicial and legislative challenges to the use of that authority.

\section{USE OF EMINENT DOMAIN FOR ENERGY DEVELOPMENT}

The Fifth Amendment to the U.S. Constitution allows state and federal governments to take private property so long as it is for a "public use" and "just compensation" is paid. ${ }^{22}$ State constitutions have similar authorizations and limitations on the use of eminent domain. ${ }^{23}$ Both Congress and state legislatures have exercised this authority since the na-

analyses as may be directed by the legislature"; and requiring Washington State Department of Health to "develop a cumulative impact analysis to designate the communities highly impacted by fossil fuel pollution and climate change in Washington"); S. 1679, 129th Leg., 1st Reg. Sess., at 4-11 (Me. 2019) (requiring adoption of state climate action plan and creating Maine Climate Change Council). For state population figures, see Benjamin Elisha Sawe, The 50 U.S. States Ranked by Population, World AtLas (Jan. 9, 2020), https://www.worldatlas.com/articles/us-states-by-population.html [https://perma.cc/V5AE-8W6S].

22. U.S. CONST. amend. V; see also William Baude, Rethinking the Federal Eminent Domain Power, 122 YALE L.J. 1738, 1745 (2013) ("Eminent domain is the sovereign's power to take property-paradigmatically land - without its owner's consent.").

23. See, e.g., Maureen E. Brady, The Damaging Clauses, 104 VA. L. REV. 341, 341 (2018) (discussing takings provisions in state constitutions). 
tion's founding to build roads, highways, bridges, schools, water and sewage systems, and other projects when voluntary property transactions with affected landowners are unsuccessful. ${ }^{24}$ As described in this Part, Congress and state legislatures have also delegated eminent domain authority to private actors to build a range of projects designed to serve the public, such as electric transmission lines and oil and gas pipelines.

\section{A. State and Federal Eminent Domain Authority for Energy Projects}

The bulk of eminent domain authority for private companies to build energy projects exists at the state level. While federal law governs the use of eminent domain for interstate natural gas pipelines, state law governs the use of eminent domain for energy generating plants as well as for virtually all electric transmission lines, oil pipelines, and intrastate natural gas pipelines. Thus, in order to use eminent domain authority to build any oil pipeline; an intrastate natural gas pipeline; any pipeline proposed to transport ethane propane, butane, or other "natural gas liquids" or "NGLs"; ${ }^{25}$ or most electric transmission lines, there must be authority under state law because Congress has not created federal eminent

24. For general discussions of the justifications for eminent domain, see Abraham Bell, Private Takings, 76 U. CHI. L. REV. 517, 545-46 (2009); Lawrence Berger, The Public Use Requirement in Eminent Domain, 57 OR. L. REV. 203 (1978); RICHARD Epstein, Takings: Private Property and the Power of Eminent Domain 161-81 (1985); Thomas W. Merrill, The Economics of Public Use, 72 CoRnell L. ReV. 61 (1986); Frank I. Michelman, Property, Utility and Fairness: Comments on the Ethical Foundations of “Just Compensation," 80 HARV. L. REV. 1165 (1967); Patricia Munch, An Economic Analysis of Eminent Domain, 84 J. PoL. ECON. 473 (1976).

25. According to the Congressional Research Service,

NGLs, which make up about [four percent] of the U.S. energy mix, include ethane, propane, butane, isobutane, and pentanes (which includes natural gasoline). The United States is the largest producer of NGLs in the world. NGLs are differentiated from one another by the number of carbon atoms in their molecular chain. Natural gas liquids are extracted as a mixture of hydrocarbons and other gases and are produced and separated from one of two sources: natural gas processing or crude oil refining.

Cong. Research Serv., Natural Gas Liquids: The Unknown Hydrocarbon (2018); see also U.S. DeP'T of Energy, Natural Gas Liquids Primer: With a Focus ON the APPALACHIAN REGION 1 (2018) (discussing NGLs). In contrast to natural gas pipelines, pipelines that transport NGLs are not eligible for federal eminent domain authority under the Natural Gas Act and instead obtain any required permits and eminent domain authority under state law, similar to oil pipelines. See, e.g., David L. Wochner, FERC's Jurisdiction Now Reaches Ethane Pipelines Too, LAw360 (Feb. 27, 2014, 5:18 PM), https://www.law360.com/articles/513489/ferc-s-jurisdiction-now-reaches-ethanepipelines-too (describing federal jurisdiction over NGL pipelines as extending to rates and conditions of service under the Interstate Commerce Act (similar to oil pipelines) but not to the siting, construction, abandonment, or transfer of facilities as would be true if jurisdiction were under the Natural Gas Act). 
domain authority for these projects. Most states have statutes that define what projects are a "public use" eligible to exercise eminent domain authority regardless of whether the party seeking to use that authority is a government actor or a private company. ${ }^{26}$

States vary significantly as to how easy or difficult it is for companies to exercise eminent domain to build these projects. For instance, Texas does not require any approval from the state regulatory commission before constructing a pipeline and exercising eminent domain but instead requires only that the pipeline certify that it is a common carrier. ${ }^{27}$ By contrast, other states, like Illinois and Minnesota, require a pipeline company to obtain a "certificate of public convenience and necessity" or similar certification that there is a "need" for the pipeline and that the economic benefits of the pipeline outweigh any environmental harm and adverse impacts on landowners. ${ }^{28}$ Only after receipt of this certificate can the pipeline exercise eminent domain. ${ }^{29}$ Most states also require similar certificates before an electric utility or other company can build an electric transmission line and exercise eminent domain to obtain the property rights needed to build the line. ${ }^{30}$ Based on these laws, oil and gas pipeline companies and electric utilities regularly exercise or threaten to exercise eminent domain authority when landowners resist entering into voluntary easement agreements for the land required to build the project.

Federal eminent domain authority exists only for select private energy projects - namely, where Congress has found a particular need to extend such authority to overcome state property law barriers to projects deemed in the national interest. For instance, in the 1940s, U.S. cities in the northeastern United States became more dependent on natural gas for heating and industry, but landowners in other states, along with coal and railroad interests, blocked efforts to construct the pipelines needed to transport the gas from where it was produced in Texas, Oklahoma, and other southwestern states. ${ }^{31}$ Momentum built in Congress to create a federal process for interstate natural gas pipelines that would override state opposition, resulting in nationwide eminent domain authority being extended to pipeline companies in 1947 through amendments to the Natural

26. See, e.g., Minn. Stat. § 117.025(11) (2019); Colo. Rev. Stat. § 38-1101(1)(b)(I) (2019); N.H. REV. STAT. ANN. § 498-A:2(VII) (2019).

27. See Alexandra B. Klass \& Hannah J. Wiseman, Energy Law 24 (2d ed. 2020).

28. Id.

29. Id.

30. Id. at 19 .

31. Alexandra B. Klass \& Danielle Meinhardt, Transporting Oil and Gas: U.S. Infrastructure Challenges, 100 IowA L. REV. 947, 996-99 (2015) (describing history). 
Gas Act of $1938 .^{32}$ This statute delegated to the Federal Power Commission (the predecessor to today's Federal Energy Regulatory Commission) the authority to grant interstate natural gas pipelines a Certificate of Public Convenience and Necessity if economic and environmental conditions are met. ${ }^{33}$ Once the pipeline owner obtains the certificate, federal law grants the certificate holder nationwide eminent domain authority to build the pipeline if it is not able to obtain voluntary easements from all landowners in the pipeline's path. ${ }^{34}$

Likewise, Congress created federal eminent domain authority for interstate oil pipelines during World War II after German forces cut off shipping routes for oil transport up the eastern seaboard in the Atlantic Ocean. ${ }^{35}$ Pipeline companies had attempted to build interstate pipelines as a substitute form of transportation, but Georgia blocked the projects, refusing to grant permits or allow the use of eminent domain. ${ }^{36}$ Congress responded by creating federal eminent domain authority to build those pipelines and override state opposition. ${ }^{37}$ That law, however, unlike the federal law governing interstate natural gas pipelines, was time-limited and thus, at the end of the war, eminent domain for oil pipelines once again became solely a subject of state law. ${ }^{38}$

Notably, the expansion and contraction of eminent domain authority for private industry over time exists well beyond the energy sector. For instance, in the early nineteenth century, states throughout the country delegated to private transportation companies and timber and manufacturing industries the right to take private property to promote "economic expansion in a country with very little surplus capital." 39 State courts initially upheld these delegations of eminent domain authority to private parties as a public use based on the public benefits of economic expansion. $^{40}$

By the early twentieth century, however, state courts in the East and Midwest had mostly retreated from this broad approach to public use when it came to private party eminent domain actions but retained it for

32. Id

33. 15 U.S.C. $§ 717 f$ (Supp. I 1946); Act of July 25, 1947, Pub. L. No. 80-245, 61 Stat. 459 (amending the Natural Gas Act); see also Minisink Residents for Envtl. Pres. \& Safety v. FERC, 762 F.3d 97, 101-02 (D.C. Cir. 2014) (describing federal process for permitting interstate natural gas pipelines under the Natural Gas Act).

34. 15 U.S.C. $\S 717 \mathrm{f}(\mathrm{h})(2018)$.

35. Klass \& Meinhardt, supra note 31, at 962-63.

36. Id. (detailing history).

37. Id.; Act of July 30, 1941, Pub. L. No. 77-197, 55 Stat. 610 (Cole Act).

38. Klass \& Meinhardt, supra note 31, at 962-63.

39. Special Report, The Private Use of Public Power: The Private University and the Power of Eminent Domain, 27 VAND. L. REV. 681, 690-91 (1974).

40. Id. at 691-93. 
government-initiated eminent domain actions. For instance, courts in Illinois, Virginia, and West Virginia invalidated state laws delegating eminent domain authority to private industry, including coal and timber companies, on grounds that the exercise of eminent domain by private companies to build roads, tramways, and railroad connections to serve their businesses rather than the general public was not a public use. ${ }^{41}$ By contrast, many states in the West, which were still in the early stages of building their economies, continued to follow a broad approach to public use, going so far as to enshrine such private eminent domain rights in their state constitutions. ${ }^{42}$

This variety of approaches to eminent domain both over time and geography shows that state legislatures and state courts have always viewed eminent domain as a public policy tool. The U.S. Supreme Court itself recognized the connection between public policy and eminent domain in Kelo v. City of New London, ${ }^{43}$ described in more detail below, when it affirmed a city's use of eminent domain to support a private redevelopment project that was designed to promote job growth and increase the city's tax base. ${ }^{44}$ In upholding the redevelopment project as a public use under the Fifth and Fourteenth Amendments, the Court cited the long history of states delegating to private parties the right of eminent domain to support mining, milling, and timber development for economic growth, as well as the state prerogative to eliminate or reduce those rights if they choose. ${ }^{45}$

\section{B. Lawsuits Challenging the Use of Eminent Domain for Energy Development}

As described above, the use of eminent domain authority by private actors to build energy projects is longstanding and widespread. For most of its history, it was also fairly uncontroversial. The "public use" associated with the development of infrastructure projects for electricity, oil, and natural gas was well accepted; there were no real alternatives to fossil fuels to power the nation's electricity and transportation sectors; and climate change was not on the radar. While there were occasional legal challenges to the "public use" designation for particular infrastructure projects - an environmental group opposing an electric transmission line through a park or landowners challenging a pipeline across their

41. Alexandra B. Klass, The Frontier of Eminent Domain, 79 U. CoLO. L. REV. 651, 656 n.15 (2008) (citing cases).

42. Id. at 657-59.

43. 545 U.S. 469 (2005).

44. Id. at $477-84$.

45. Id. at 479-89. 
lands ${ }^{46}$ - these were rarely successful and generally did not generate support beyond citizens directly impacted by the project. ${ }^{47}$ In the past fifteen years, however, a perfect storm of three unrelated, significant events has completely changed the status quo.

First came the U.S. Supreme Court's 2005 decision in Kelo v. City of New London, which, on the surface, had little to do with energy projects. ${ }^{48}$ In Kelo, the Supreme Court held 5-4 that a city's use of statedelegated eminent domain authority to take private, residential property for an urban redevelopment project was a "public use" under the Fifth Amendment. ${ }^{49}$ In reaching its decision, the majority relied on prior precedent interpreting public use to include a broad range of public purposes, including economic redevelopment, to support the conclusion that public use included private development designed to create new jobs and grow a city's tax base. ${ }^{50}$ The majority made clear, however, that states could provide stronger protections for their citizens' private property rights through narrower definitions of public use in their state constitutions or state statutes. ${ }^{51}$ The Kelo decision received a significant amount of press and remained in the national spotlight for a surprisingly long time. ${ }^{52}$ It prompted over forty states to amend their state constitutions or eminent domain statutes by 2007 to limit or prohibit the use of eminent domain for economic redevelopment purposes and to otherwise create enhanced rights for private property owners in eminent domain actions. ${ }^{53}$ These changes to state law did not expressly target energy projects. Nevertheless, the heightened attention to private property rights coupled with states' willingness to restrict or eliminate longstanding "public use" designations encouraged landowners and others to raise public use challeng-

46. See, e.g., Puntenney v. Iowa Utils. Bd., 928 N.W.2d 829, 848 (Iowa 2019) (discussing the longstanding use of eminent domain for oil pipeline projects).

47. See, e.g., Philip Nichols, Jr., The Meaning of Public Use in the Law of Eminent Domain, 20 B.U. L. REV. 615, 615 (1940) (lamenting in 1940 that the role of public use in the law of eminent domain "has never figured in the constitutional cases which have aroused passionate controversy, nor in those whose names are known to the lay public ..."); EPSTEIN, supra note 24, at 161-62, 172 (stating in 1985 in the introduction to a chapter on public use that "[t]o judge from the cases and the scholarship on the subject, this chapter largely deals with an empty question" and that "[s]cholarly commentators have rivaled each other in their efforts to read the [public use] limitation out of the Constitution").

48. Kelo, 545 U.S. at 469.

49. Id. at $472-77,484$.

50. Id. at $480-83$.

51. Id. at 489 .

52. Ilya Somin, The Grasping Hand: KELO V. City of NEW LONDON AND THE LiMITS OF EMINENT DOMAIN 135-37 (2015).

53. See id. at 135-60. According to Professor Somin, "[t]he Kelo backlash led to more new state legislation than that generated by any other Supreme Court decision in history." Id. at 135 . 
es to eminent domain actions by government and private actors, including for energy projects. ${ }^{54}$

Second, beginning in 2007, the commercialization of hydraulic fracturing and directional drilling technologies radically altered the U.S. energy landscape. After decades of concern over dwindling U.S. oil and gas production and growing U.S. reliance on the Middle East and other countries for oil and gas imports, hydraulic fracturing created almost overnight a wealth of domestic oil and gas resources. In 2019, U.S. oil production exceeded twelve million barrels per day for the majority of months that year, and is anticipated to increase in future years. ${ }^{55}$ Likewise, the U.S. Energy Information Administration forecasts that U.S. natural gas production and exports will continue to rise. ${ }^{56}$ This, in turn, has led to billions of dollars of investment in pipelines and related oil and gas infrastructure to accommodate the growth in production and transport these fossil fuel products to refineries, consumers, and export terminals. ${ }^{57}$ To build these projects, the oil and gas industry must obtain

54. Timothy Egan, Ruling Sets Off Tug of War Over Private Property, N.Y. Times (July 30, 2005), https://www.nytimes.com/2005/07/30/us/ruling-sets-off-tug-ofwar-over-private-property.html [https://perma.cc/HZ4G-WYPC] (discussing post-Kelo legal challenges to government use of eminent domain); James W. Coleman \& Alexandra B. Klass, Energy and Eminent Domain, 104 MinN. L. REV. 659, 681-82 (2019) (discussing legal challenges to private party use of eminent domain to build energy projects).

55. U.S. Field Production of Crude Oil, U.S. ENERGY InFo. ADMin., https://www.eia.gov/dnav/pet/hist/LeafHandler.ashx?n=pet\&s=mcrfpus $2 \& \mathrm{f}=\mathrm{m}$

[https://perma.cc/L82V-37TK]; Short-Term Energy Outlook, U.S. Liquid Fuels, U.S. ENERGY INFO. ADMIN. (Jan. 14, 2020), https://www.eia.gov/outlooks/steo/report/us_oil.php [https://perma.cc/MYZ6-JRPB]; see also Clifford Krauss, U.S. Oil Companies Find Energy Independence Isn't So Profitable, N.Y. TIMES (June 30, 2019), https:/www.nytimes.com/2019/06/30/business/energyenvironment/oil-companies-profit.html [https://perma.cc/CEF9-5459] ("Domestic oil production has increased by more than [sixty] percent since 2013, to over [twelve] million barrels a day, making the United States the biggest producer of oil and natural gas in the world and slashing imports. That growth has also reduced the clout and profits of the Organization of the Petroleum Exporting Countries and Russia, enabling President Trump to impose sanctions on Iran and Venezuela without risking higher gasoline prices or shortages.").

56. Short-Term Energy Outlook, Natural Gas, U.S. ENERGY INFO. AdMIN. (Jan. 14, 2020), https://www.eia.gov/outlooks/steo/report/natgas.php [https://perma.cc/A8EM2B7T]; United States Has Been a Net Exporter of Natural Gas for More Than 12 Consecutive Months, U.S. ENERGY INFO. ADMIN. (May 2, 2019), https://www.eia.gov/todayinenergy/detail.php?id=39312 [https://perma.cc/FXH4-LPZ5].

57. James W. Coleman, Pipelines \& Power-Lines: Building the Energy Transport Future, 80 Oніо ST. L.J. 263, 265 (2019); see also Christopher Serkin \& Michael P. Vandenbergh, Prospective Grandfathering: Anticipating the Energy Transition Problem, 102 MinN. L. REV. 1019, 1032-33 (2018) (summarizing data showing that the natural gas industry made $\$ 130$ billion in capital investments in natural gas plants between 2001 and 2015 and is estimated to invest an additional thirty-one billion dollars 
easements over more and more private and public lands, coming into more frequent contact with landowners who oppose the invasion of their property rights.

Last, in the late 2000s, tax credits and other financial support for wind and solar energy over the prior decade coupled with technological developments in the industry began to show results. Electric utilities began to embrace renewable energy as a viable alternative to fossil fuel use in the electricity sector first in response to state RPS mandates and later as a result of favorable economics. ${ }^{58}$ At the same time, the election of President Barack Obama in 2008 and the near-passage of federal climate change legislation in 2009 focused a national spotlight on climate change concerns. ${ }^{59}$ There was now a recognized national and international problem - climate change - and a feasible long-term solution-replacing fossil fuels with cost-effective clean energy technologies.

These three events, taken together, have resulted in a growing number of lawsuits across the country to stop new fossil fuel infrastructure projects such as natural gas pipelines in the East and the Keystone XL, Dakota Access, and other controversial oil pipelines in the Midwest and South. ${ }^{60}$ Many of the plaintiffs in these lawsuits are an unlikely coalition of private property rights advocates representing affected landowners and environmental groups who, in most other circumstances, are rarely on the same side of lawsuits. ${ }^{61}$ Not surprisingly, the focus in these cases is gen-

between 2018 and 2020, with related pipeline infrastructure designed to last for more than fifty years).

58. See, e.g., Benjamin Storrow, 'It's Just Economics.' Wind Blows Past Coal in Texas, E\&E News: ClimAtewiRE (July 23, 2019), https://www.eenews.net/climatewire/2019/07/23/stories/1060775959 (reporting on growth of wind power in Texas even in the absence of renewable energy mandates as a result of transmission expansion in the state and low prices).

59. See Randy Showstack, Can Bold U.S. Federal Climate Legislation Be Enacted Now?, EARTH \& SPACE SCI. NEWS (June 7, 2019), https://eos.org/articles/can-boldu-s-federal-climate-legislation-be-enacted-now [https://perma.cc/Z64F-F3KZ] (discussing American Clean Energy and Security Act of 2009 (also known as the "WaxmanMarkey bill") and its impact on public awareness of climate change concerns since that time).

60. See, e.g., Paul Hammel, Eminent Domain Process for Keystone XL Pipeline Begins in Nebraska, OMAHA WORLD-HERALD (Sept. 28, 2019), https://www.omaha.com/news/nebraska/eminent-domain-process-for-keystone-xlpipeline-begins-in-nebraska/article_be96c7a6-6063-55a0-a90d-37788ddd9a52.html [https://perma.cc/4D5H-Z9Z9]; Stephen Gruber-Miller, Dakota Access Pipeline was Justified in Using Eminent Domain, Iowa Supreme Court Rules, Des MoINES REG. (May 31, 2019, 9:22 AM), https://www.desmoinesregister.com/story/news/crime-andcourts/2019/05/31/iowa-supreme-court-dakota-access-pipeline-iowa-utilities-boardsierra-club-lawsuit-appeal/1286508001/ [https://perma.cc/J3X2-56XC]; infra notes 6471 and accompanying text (discussing legal challenges to new natural gas pipelines).

61. Hammel, supra note 60; Gruber-Miller, supra note 60; see also Coleman \& Klass, supra note 54, at 680-81, 688 (discussing how environmental advocacy groups 
erally on private property rights, public use, and Kelo, rather than any argument that fossil fuel projects are not a public use because they contribute to climate change. ${ }^{62}$ Indeed, it would be difficult to find support for such an argument under existing eminent domain statutes that have specifically defined oil and gas pipelines as a "public use" for nearly a century. ${ }^{63}$

\section{FEDERAL COURT LEGAL CHALLENGES TO NEW NATURAL GAS PIPELINES}

At the federal level, environmental groups and landowners have filed lawsuits challenging decisions by the Federal Energy Regulatory Commission (FERC) to approve the use eminent domain authority by natural gas pipeline companies on grounds that the projects in question fail to meet the minimum requirements of the Natural Gas Act and Kelo. To date, plaintiffs have not prevailed in any of these lawsuits. ${ }^{64}$ Nevertheless, continued litigation over the use of eminent domain, as well as separate lawsuits over the climate, water quality, and other environmental impacts of these projects brought under federal environmental statutes such as the National Environmental Policy Act and the Clean Water Act,

and defenders of private property rights, typically opposed ideologically, are uniting to fight eminent domain claims for fossil fuel projects).

62. See Coleman \& Klass, supra note 54, at 681-82, 688.

63. See Klass \& Meinhardt, supra note 31, at 1027-53 (surveying the eminent domain laws for oil pipelines in all 50 states). One exception to this general rule that all oil and gas pipelines are a public use under state law is in Colorado, where the Colorado Supreme Court held in 2012 that the statute granting eminent domain authority to pipelines did not include oil pipelines but instead was limited to pipelines carrying power, water, air, or gas. The court focused on the fact that the statute nowhere mentioned oil or petroleum and that it must narrowly construe laws that grant eminent domain power to private parties. Larson v. Sinclair Transp. Co., 284 P.3d 42, 44-45 (Colo. 2012) (en banc). Other states, by contrast, expressly include oil pipelines in their statutes conveying eminent domain authority even if they differ with regard to the requirements for exercising that authority. See Klass \& Meinhardt, supra note 31, at 1027-53.

64. See, e.g., Bold All. v. Fed. Energy Regulatory Comm'n, No. 17-cv-01822 (RJL), 2018 WL 4681004 (D.D.C., Sept. 28, 2018); Berkley v. Mountain Valley Pipeline, No. 7:17-cv-00357, 2017 WL 6327829 (W.D. Va., Dec. 11, 2017), aff'd, 896 F.3d 624 (4th Cir. 2018), cert. denied, 139 S. Ct. 941 (2019); New Jersey Conservation Found. v. Fed. Energy Regulatory Comm'n, 353 F. Supp. 3d 289 (D.N.J. 2018); Appalachian Voices v. Fed. Energy Regulatory Comm'n, No. 17-1271, 2019 WL 847199, at *2 (D.C. Cir., Feb. 19, 2019) ("Mountain Valley's exercise of eminent domain authority for purposes of this project poses no Takings Clause problems from either a 'public use' or 'just compensation' perspective."). But see City of Oberlin v. Fed. Energy Reg. Comm'n, 937 F.3d 599, 601-603, 606-08 (D.C Cir. 2019) (remanding natural gas pipeline certificate order to FERC for further explanation as to why a natural gas pipeline proposed in part to export gas to Canada is a public use under the Fifth Amendment and a public convenience and necessity under the Natural Gas Act). 
may result in significant delays and will certainly increase the costs of permitting and construction. ${ }^{65}$

Moreover, several high-profile natural gas pipeline decisions in 2019 may lead to additional federal court scrutiny of the use of eminent domain for these projects, as well as public attention to the issue. In Oberlin v. Federal Energy Regulatory Commission, ${ }^{66}$ the D.C. Circuit remanded a pipeline certificate order to FERC on grounds that FERC had failed to sufficiently explain why a natural gas pipeline proposed in part to export natural gas to Canada served the public convenience and necessity under the Natural Gas Act or was a public use under the Fifth Amendment Takings Clause. ${ }^{67}$ In another case, the D.C. Circuit agreed to re-hear en banc a challenge to FERC's longstanding practice of issuing "tolling orders" on landowner requests for reconsideration of FERC certificate orders. ${ }^{68}$ These tolling orders have the effect of delaying for a year or more the ability of landowners to obtain judicial review of FERC's pipeline approvals and authorization of eminent domain. During that delay, the pipeline - with certificate in hand - may begin eminent domain proceedings to acquire land and construct the pipeline. Judge Millett on the D.C. Circuit has described the process as "Kafkaesque" and one that creates a "bureaucratic purgatory that only Dante could love." ${ }^{69}$ Last, the U.S. Court of Appeals for the Third Circuit held in

65. Niina H. Farah, 8 Energy Battles to Watch in 2020, E\&E NEws: ENERGYWIRE (Dec. 23, 2019), https://www.eenews.net/stories/1061883641 [https://perma.cc/FJV5-UXVK] (discussing high-profile lawsuits over energy issues, including pipelines); Pamela King, Inside the D.C. Circuit's Pipeline Docket, E\&E NEws: ENERGYWIRE (Mar. 5, 2019), https://www.eenews.net/stories/1060123105 [https://perma.cc/GCB8-E9KG] (discussing lawsuits over natural gas pipelines); Ellen M. Gilmer, Burgeoning Legal Movement Pits Landowners Against Pipelines, E\&E News: ENERGYWIRE (Sept. 17, 2017), https://www.eenews.net/stories/1060060443 [https://perma.cc/SA7F-W47W]; Carey L. Biron, Public Use and Private Profit: U.S. Landowners Question Forced Purchases, ReUTERs (Feb. 5, 2019, 2:27 AM), https://de.reuters.com/article/usa-land-lawmaking/feature-public-use-and-private-profitu-s-landowners-question-forced-purchases-idUKL8N1ZP57L [https://perma.cc/Y2G7MR8B]; Gregory S. Schneider, As Court Challenges Pile Up, Gas Pipeline Falls Behind, WASH. Post (Dec. 31, 2018, 1:31 PM), https://www.washingtonpost.com/local/virginiapolitics/as-court-challenges-pile-up-gas-pipeline-falls-behind/2018/12/29/8637dbd20549-11e9-b5df-5d3874flac36_story.html [https://perma.cc/B92G-CTWP]; Pamela King, Rural Families' Eminent Domain Fight Arrives at High Court, E\&E News: ENERGYWIRE (May 17, 2019), https://www.eenews.net/stories/1060345715 [https://perma.cc/9ZL4-MAD7]. For a discussion of litigation over GHG emissions from new natural gas pipelines, see JAYME HeIN ET AL., InST. FOR POLICY INTEGRITY, PIPELINE APPROVALS AND GREENHOUSE GAS EMISSIONS (2019).

66. 937 F.3d 599 (D.C. Cir. 2019).

67. Id. at 601-03, 606-08.

68. Allegheny Def. Project v. Fed. Energy Reg. Comm'n, 932 F.3d 940 (D.C. Cir. 2019), rehearing en banc granted (D.C. Cir. 2019).

69. Id. at 948, 956 (Millett, J., concurring). 
PennEast Pipeline Company ${ }^{70}$ that a pipeline company could not exercise eminent domain over state lands (or private lands subject to a state conservation easement) because the Natural Gas Act did not delegate to private parties the federal government's exemption from Eleventh Amendment sovereign immunity and, even if Congress had intended to do so, it was unlikely such a delegation would be constitutional. ${ }^{71}$

These recent cases as a group show the use of eminent domain for these federal projects is at the very least "in play" in a way not seen in the past for energy projects. While congressional action is unlikely, the focus on use and abuse of eminent domain for interstate natural gas pipelines may help galvanize support for reform at the state level when it comes to projects that rely on state law governing eminent domain.

\section{STATE COURT LEGAL CHALLENGES TO NEW OIL AND NGL PIPELINES}

At the state level, plaintiffs have had somewhat more success opposing the use of eminent domain for energy projects but the record remains mixed. In 2015, the Kentucky Court of Appeals held that a proposed natural gas liquids or "NGL" pipeline through Kentucky to deliver product to the Gulf of Mexico was not in "public service" because it would not deliver product to state citizens and thus the pipeline could not exercise eminent domain authority under the applicable statute. ${ }^{72}$ In 2016, the West Virginia Supreme Court held in the absence of a federal certificate, which the natural gas company in question had not yet obtained, the company could not exercise eminent domain in the state because no West Virginia customers would receive the gas flowing through the pipeline. ${ }^{73}$

By contrast, in 2019, the Iowa Supreme Court rejected arguments by landowners and the Sierra Club that the controversial Dakota Access pipeline through North Dakota, South Dakota, Iowa, and Illinois was not a "public use" in Iowa because it did not pick up or drop off petroleum products in the state. ${ }^{74}$ The court disagreed with the analysis of the Kentucky and West Virginia courts described above, and held that oil was "essential to Iowa's economy" and thus the common carrier pipeline transporting it was a public use under the state's eminent domain statute, the Iowa Constitution, and the U.S. Constitution. ${ }^{75}$ The court relied on

\footnotetext{
70. 938 F.3d 96 (3d Cir. 2019).

71. Id. at 104, 111-13.

72. Bluegrass Pipeline Co. v. Kentuckians United to Restrain Eminent Domain, 478 S.W.3d 386 (Ky. Ct. App. 2015). 2016).

73. Mountain Valley Pipeline, LLC v. McCurdy, 793 S.E.2d 850 (W. Va.

74. Puntenney v. Iowa Utils. Bd., 928 N.W.2d 829, 844, 849-51 (Iowa 2019).

75. Id. at 851 .
} 
decisions from Illinois and Ohio in holding that the pipeline "provides public benefits in the form of cheaper and safer transportation of oil, which in a competitive marketplace results in lower prices for petroleum products," and thus benefits "all consumers of petroleum products, including three million Iowans." ${ }^{76}$ Notably, the court recognized that facilitating the continued development of fossil fuels would contribute to the problem of climate change. ${ }^{77}$ Nevertheless, it rejected the idea that it could take that into consideration in interpreting the state's eminent domain statute and suggested that perhaps "as a matter of policy, a broadbased carbon tax that forced all players in the marketplace to bear the true cost of their carbon emissions should be imposed." ${ }^{78}$

In each of these cases, state courts interpreted the scope of the public use provisions in their state eminent domain statutes and constitutions against the backdrop of Kelo, existing state court decisions on public use, and any post-Kelo legislative reforms narrowing the definition of public use. But without legislative reforms targeting the energy sector specifically, the ability of plaintiffs to successfully challenge the use of eminent domain for oil and NGL pipelines will likely be limited to situations like the ones in West Virginia and Kentucky, where plaintiffs can show that no citizens in the state will receive the oil or NGLs in the pipeline and that there is no related public use or public purpose. As a result, some pipelines may be stopped through this analysis, but most will not be, particularly pipelines proposed specifically to bring oil or NGLs to the states in question for refining or consumption or where the court recognizes national benefits of oil and NGL transportation, as in the Iowa, Illinois, and Ohio cases. This is because virtually all states define these pipelines as a "public use" by statute, making it difficult for landowners to challenge eminent domain for oil or NGL pipelines in the absence of state legislative reform. ${ }^{79}$

76. Id. at 849-51; see also Enbridge Energy (Illinois), LLC v. Kuerth, 99 N.E.3d 210, 218 (Ill. App. Ct. 2018) (rejecting claim that public use determination was based on who "uses" the pipeline rather than who "benefits" from the pipeline); Sunoco Pipeline L.P. v. Teter, 63 N.E.3d 160, 173-74 (Ohio Ct. App. 2016) ("The products, propane and butane, being transported are used to heat homes and as an additive to gasoline. Propane and butane are also used in the production of many products our society uses every day. Thus, the transportation of propane and butane provides more than economic benefit to Ohio, it provides some of the necessities of life.").

77. Puntenney, 928 N.W.2d at 851-52.

78. Id. at 851 .

79. See Klass \& Meinhardt, supra note 31, at 982-83, 1027-53 (discussing laws in all fifty states). 


\section{MINIMAL LEGISLATIVE EMINENT DOMAIN REFORM FOR ENERGY PROJECTS}

To date, there have been few changes to state statutes governing the use of eminent domain for energy projects and no movement in Congress to alter eminent domain law for interstate natural gas pipelines. As noted above, the Kelo "revolution" in the states focused on government use of eminent domain for economic redevelopment projects, and left the energy industry's use of eminent domain for oil and gas pipelines mostly alone. This is not surprising because the rapid expansion of oil and gas pipeline infrastructure did not start until a few years after state legislatures completed their post-Kelo reform efforts. Two notable exceptions to this legislative inaction are in Georgia and South Carolina, where state legislatures in 2016 enacted moratoria on the use of eminent domain for new oil and NGL pipelines in response to landowner opposition to the proposed Palmetto oil pipeline.$^{80}$ Both moratoria have resulted in new, stricter regulations on the use of eminent domain for oil and NGL pipelines, but are not intended to completely ban fossil fuel pipelines in general. ${ }^{81}$ In both states, although environmental groups helped behind the scenes in the legislative reform efforts, the public face of the opposition focused on property rights rather than environmental protection or climate change, consistent with those states' political leanings. ${ }^{82}$ Neverthe-

80. H.B. 1036, Gen. Assemb., 2015-16 Reg. Sess. (Ga. 2016) (moratorium on eminent domain for oil and NGL pipelines); S.B. 868, 121st Gen. Assemb., Reg. Sess. (S.C. 2016) (same); Gillian Neimark, In Georgia and South Carolina, "The Game Has Changed" on Oil Pipelines, Energy News Network (Mar. 14, 2017), https://energynews.us/2017/03/14/southeast/in-georgia-and-south-carolina-the-game-haschanged-on-oil-pipelines/ [https://perma.cc/95DC-DNE2] (describing how both states enacted temporary moratoria on oil pipelines).

81. H.B. 413, Gen. Assemb., 2017-18 Reg. Sess. (Ga. 2017) (enacting certificate requirement and other procedures before eminent domain can be exercised); Mary Landers, New Gas, Oil Pipeline Rules in the Works for Georgia, SaVAnNAH Now (Apr. 6, 2018, 3:53 PM), https:/www.savannahnow.com/news/20180406/new-gas-oil-pipelinerules-in-works-for-georgia [https://perma.cc/F28J-4V2D]. Even in Texas, where there is significant legal and political support for the oil and gas industry, there have been recent efforts to create additional landowner rights in the eminent domain process. See Carlos Anchondo, Eminent Domain Reform Died in the Texas Legislature This Session, The $\begin{array}{lllll}\text { TEXAS TRIBUNE } & \text { (May 27, 2019, } & \text { 2:00 }\end{array}$ https://www.texastribune.org/2019/05/27/eminent-domain-reform-died-in-the-texaslegislature/ [https://perma.cc/4LVJ-YSYE] (discussing failed legislative efforts to require public meetings between property owners and industry groups as well as measures to prevent "low-ball" offers to property owners and prospects for success in future legislative sessions).

82. See Corporate Crime Reporter, How the Kinder Morgan Palmetto Pipeline was Defeated (Nov. 21, 2016, 10:20 AM), https://www.corporatecrimereporter.com/news/200/how-the-kinder-morgan-palmetto- 
less, the reason environmental groups have focused time, money, and effort on these challenges is that addressing climate change requires preventing the construction of new fossil fuel infrastructure that will "lockin" continued use of climate warming energy resources for many decades. $^{83}$

A related issue is the lack of eminent domain authority for certain projects that will need to be built for a clean energy transition. For instance, electric utilities generally possess eminent domain authority to build electric transmission lines if they obtain a certificate of need and a siting permit from the state's public utility commission or public service commission. ${ }^{84}$ But in recent years, "merchant" transmission line companies that do not have retail electricity customers have attempted to build interstate, long-distance transmission lines to transport wind energy to population centers but have been thwarted by state laws that either limit eminent domain authority to electric utilities or are unclear on that point, leading to litigation, delays, and failed projects. ${ }^{85}$ Many scholars and other experts have contended that the lack of clear eminent domain authority for these non-utility actors, as well as narrow definitions of "need" in state statutes regardless of what type of entity is building the line, threaten efforts to integrate more renewable energy into the nation's electric grid. ${ }^{86}$

pipeline-was-defeated/ [https://perma.cc/R8AK-6A6R] (interview with executive director of Savannah Riverkeeper regarding landowner and environmental group coalitions).

83. See, e.g., Phil McKenna, Today's Fossil Fuel Infrastructure Already Locks in 1.5C Warning, Study Warns, Inside Climate News (July 1, 2019), https://insideclimatenews.org/news/01072019/climate-change-lock-in-fossil-fuel-powerplants-paris-goals-nature-study [https://perma.cc/PAE9-EH5Y]; Alexandra B. Klass, Future-Proofing Energy Transport Law, 94 WASH. U. L. REV. 827, 828-32 (2017) (discussing concerns over path dependency and sunk investments associated with building new fossil fuel infrastructure designed to last for many decades).

84. Klass, supra note 83, at 866-67.

85. See, e.g., Ill. Landowners Alliance, NFP v. Ill. Commerce Comm'n, 90 N.E.3d 448 (Ill. 2017) (holding that a merchant transmission line company could not seek a certificate of public convenience and necessity to build a transmission line in the state, which is a precondition to exercising eminent domain); see also RuSSELL GOLD, SUPERPOWER (2019) (detailing failed efforts of merchant transmission line company Clean Line Energy Partners to build a series of interstate electric transmission lines to transport wind energy from central plains states to population centers); Alexandra B. Klass \& Jim Rossi, Revitalizing Dormant Commerce Clause Review for Interstate Coordination, 100 MINN. L. REV. 129, 190-95 (2015) (discussing state statutory and regulatory barriers for merchant transmission line companies).

86. See, e.g., Bipartisan Policy Ctr., Capitalizing on the Evolving Power Sector: Policies for a Modern and Reliable U.S. Electric Grid 28-33 (2013); Mass. Inst. of Tech., The Future of the Electric Grid 77 (2011); Ashira Pelman Ostrow, Grid Governance: The Role of a National Network Coordinator, 35 CARDOZO L. REV. 1993 (2014); Jim Rossi, The Trojan Horse of Electric Power Transmission Line Siting Authority, 39 EnVTL. L. 1015, 1018-19 (2009); Alexandra B. Klass, Transmission, 


\section{EMINENT DOMAIN LAW AS CLIMATE POLICY}

To date, state policymakers have not focused on eminent domain reform as a component of clean energy laws. The new laws are in many ways an expansion of existing RPS laws, with a focus on supporting and expanding new, carbon-free energy resources to displace existing fossil fuel resources. If fossil fuel industries were already on the decline as a matter of economics, then perhaps supporting the new energy resources would be enough, and fossil fuel resources would fade quickly on their own. At the present time, that appears to be the case for coal-fired power plants, which electric utilities are retiring rapidly in response to a combination of competition from low cost natural gas in the electricity sector, state RPSs, and more stringent regulations on coal plants adopted during the Obama administration. ${ }^{87}$ However, that is not the case when it comes to oil and natural gas, both of which are now in abundance in the United States and remain a major part of the U.S. and global economies. ${ }^{88}$ The industry is in the process of expanding its reach through new drilling sites, pipelines, storage hubs, export facilities, and associated infrastructure. ${ }^{89}$ This is where changes to eminent domain law are important-not

Distribution, and Storage: Grid Integration, in LEGAL PATHWAYS TO DEEP DeCARbonization In the United States 527, 534-36, 543 (2019); see also Jim Carlton, Idaho Needs More Power but Parts of Oregon Object, WALL ST. J. (Dec. 30, 2019, 8:30 AM), https:/www.wsj.com/articles/idaho-needs-more-power-but-parts-of-oregon-object11577712600 (discussing local opposition to new electric transmission line designed to transport renewable energy to consumers).

87. U.S. DeP'T OF ENERGy, StAFF RePort to the SECRETARY ON EleCtricity MARKETS AND RELIABILITY 13-14 (Aug. 2017) (discussing reasons for coal plant retirements); Michael R. Drysdale, Farewell to Coal?, 62 Rocky MT. Min. L. Inst. 17-1 (2016); Benjamin Storrow, EPA Expects Coal Decline to Continue Under ACE, E\&E NEWS: ClimatewiRE (July 1, 2019), https://www.eenews.net/climatewire/stories/1060678727 (discussing projections of future coal decline by U.S. EPA, U.S. Energy Information Administration, credit agencies, and industry actors and reasons for decline).

88. See supra notes 55-57 and accompanying text (discussing growth in U.S. oil and gas production resulting from fracking). Although the bulk of federal tax incentives now support renewable energy production, fossil fuel production still received $\$ 3.2$ billion in federal tax incentives in 2018, and that amount is expected to increase in future years. See Cong. Res. Serv., R44852, The Value of Energy TAX Incentives for DifFERENT Types of ENERGy Resources 6-7, 11-12, tbl. 2 \& fig. 2 (Mar. 19, 2019), https://fas.org/sgp/crs/misc/R44852.pdf [https://perma.cc/9YJH-H5K8].

89. See, e.g., McKenna, supra note 83 (discussing fossil fuel infrastructure expansion); Coleman, supra note 57 (same); U.S. DEP'T OF ENERGY, ETHANE STORAGE AND Distribution Hub in the United States (2018); James Bruggers, Plastics: The New Coal in Appalachia, Inside Climate News (Feb. 25, 2019), https://insideclimatenews.org/news/25022019/plastics-hub-appalachian-fracking-ethanecracker-climate-change-health-ohio-river [https://perma.cc/Y9GF-SQXM]. 
as a substitute for state clean energy laws but as an additional and important property-based tool to support those laws.

\section{A. The Limits of Current Eminent Domain Lawsuits and the Role of Legislative Reform}

The landowner and environmental lawsuits challenging public use for oil and gas pipelines have been very effective at keeping climate issues in the press and forcing the public to recognize the role that new fossil fuel infrastructure plays in exacerbating climate change. But there are limits to their effectiveness as a legal matter. This is because state legislatures enacted the eminent domain provisions governing oil and gas pipelines precisely in order to create incentives for these projects and make them easier to build. ${ }^{90}$ Thus, it is the rare fossil fuel project that a state court will find serves no state citizen and thus is not a public use. ${ }^{91}$ Many more state courts are likely to adopt the view of the Iowa, Illinois, and Ohio courts, which have all held that public use, under current constitutional and statutory law, includes private fossil fuel projects designed to lower the costs of oil and gas resources. ${ }^{92}$ This is why legislative reform in this area is so critical and should be a central part of state climate policies rather than an unrelated property issue to be addressed by a separate legislative committee at another time.

The states that have enacted aggressive clean energy laws must accomplish two distinct goals even if they don't fully acknowledge it. First, they must prompt the private sector to build new infrastructure to generate the carbon-free energy required to meet the new mandates. Second, they must discourage the continued building of fossil fuel infrastructure despite the present-day profitability of such activity. The state climate policies to date focus on the first goal by imposing mandates for carbonfree electricity, provisions for helping utilities recover some of their investments in fossil fuel plants, and helping state citizens with the energy

90. See e.g., Puntenney v. Iowa Utils. Bd., 928 N.W.2d 829, 848-49 (Iowa 2019) (discussing long history of state delegation of eminent domain authority to private companies to build railroads, pipelines, and other infrastructure and citing prior case law stating that "if the public interest can be in any way promoted by the taking of private property, it must rest in the wisdom of the legislature, to determine whether the benefit to the public will be of sufficient importance to render it expedient for them to exercise the right of eminent domain and to interfere with the private rights of individuals for that purpose.") (quoting Stewart v. Bd. of Supervisors, 30 Iowa 9, 19-21 (1870)).

91. See, e.g., Bluegrass Pipeline Co. v. Kentuckians United to Restrain Eminent Domain, 478 S.W.3d 386, 392 (Ky. Ct. App. 2015) (describing evidence that the legislature only delegated eminent domain authority to companies that would be regulated by state public utility commission); Mountain Valley Pipeline, LLC v. McCurdy, 793 S.E.2d 850 (W. Va. 2016) (involving a private pipeline that was not a common carrier).

92. See supra notes 74-78 and accompanying text (discussing cases). 
transition. ${ }^{93}$ Certainly, these efforts will help bring about a shift toward carbon-free resources that can displace existing fossil fuel resources. But none of the state policies to date contain any property-related provisions for addressing the second goal-discouraging continued investment in fossil fuel resources, particularly oil and natural gas resources that, unlike coal, remain a growing part of the U.S. economy. As a result, states are leaving on the table an important property-based policy tool that can support existing and proposed laws promoting clean energy.

Importantly, legislative eminent domain reform can help accomplish both goals-building new clean energy projects and discouraging new fossil fuel energy projects - and can complement the financial incentives, technology development, and other existing components of state climate policies. In order for eminent domain to be used effectively to accomplish state climate policy goals it must be used as both an incentive and a disincentive. In other words, policymakers must change eminent domain policy to make it easier to build carbon-free infrastructure and they must change eminent domain policy to make it harder to build fossil fuel infrastructure. That means the power of eminent domain must be extended to some actors and projects that do not currently possess it and must be withdrawn from some actors and projects that have possessed it for a long time.

This dual approach is new. Generally, changes to eminent domain law go only in one direction at a time. Congress and states delegate eminent domain authority for particular projects when they want to make it easier to build them-railroads, pipelines, and transmission lines are examples. The state legislative reaction to the Kelo case is an example in the opposite direction - in response to the Supreme Court's decision, policymakers in over forty states significantly limited the ability of state and local governments to exercise eminent domain authority for economic redevelopment projects. ${ }^{94}$ Using eminent domain law as a component of climate policy should explicitly recognize the role of eminent domain in the energy sector as an incentive to both build projects and to stop projects at the same time.

93. See supra note 5 and accompanying text (discussing state legislation).

94. Larry Morandi, State Eminent Domain Legislation and Ballot Measures, NAT'L CONF. St. Legislatures (Jan. 1, 2012), https://www.ncsl.org/research/environment-and-natural-resources/eminent-domainlegislation-and-ballot-measures.aspx [https://perma.cc/Y527-LT87]; supra note 53 and accompanying text (discussing the legislative response to the Kelo decision). 


\section{B. Evaluating Which Energy Projects Should be Subject to Reform}

States enacting clean energy policies should consider eliminating some or all fossil fuel projects - generation plants, pipelines, and related infrastructure - from the definition of "public use" in state statutes granting eminent domain authority. Doing so allows states to make a clear statement that these projects are now disfavored. Each state seeking to make a change to its eminent domain policy will need to consider which projects to target. Of course, many states have no interest in phasing out fossil fuels at the present time, particularly states like Texas, Wyoming, and others with economies that rely heavily on fossil fuel extraction. But this proposal is not focused on those states, at least for now. Instead, it targets the states that have indicated that they are serious about climate policy, even if it means major changes in how the states procure and use energy.

Importantly, the approach to eminent domain reform should not necessarily be the same in all the states seeking to implement aggressive clean energy laws. For instance, whether natural gas should immediately be a disfavored energy resource will depend in large part on the stage of energy transition in that state as well the potential for technological development. For states, like California, Washington, and New York, that already have little or no coal generation resources remaining, one can argue natural gas should be included with coal as a disfavored resource to generate electricity. On the other hand, studies show that even in states without coal, continued use of modest amounts of natural gas can play an important role in achieving significant reductions in carbon emissions in a more cost-effective manner than a system with 100 percent renewable energy. ${ }^{95}$ Likewise, in states that still rely heavily on coal to generate electricity, there are arguments that in the short term, natural gas may be a helpful "bridge fuel" to eliminate coal, along with an increase in renewable energy, although many environmental groups disagree with that

95. See, e.g., Interview by David Spence with Arne Olson, Modeling Decarbonization in the West, ENERGYTRADEOFFS (June 16, 2019), https://www.energytradeoffs.com/2019/06/16/arne-olson-modeling-a-reliable-greentransition/ [https://perma.cc/4L7L-5HSA] (interview regarding clean energy transition and the role of natural gas and technology developments in achieving cost-effective decarbonization with focus on using natural gas as a backup to renewable energy when needed to address intermittency or peak load concerns). But see Jurgen Weiss, Who's Afraid of 100\%?, UTIL. DIVE (Feb. 6, 2020), https://www.utilitydive.com/news/whosafraid-of-100/571772/ [https://perma.cc/EB9Z-B77T] (contending that declining costs of renewable energy and new technology developments renders arguments "that a $100 \%$ [carbon free energy] goal is unnecessary, infeasible and too expensive - are questionable and quite likely incorrect"). 
assessment. ${ }^{96}$ Moreover, in all states, technology developments may change the approach to eminent domain. For instance, if a state wishes to support the construction of natural gas plants that integrate CCS technologies, allowing eminent domain to be used to facilitate the pipelines and other infrastructure needed for those plants could be consistent with a strong climate policy. ${ }^{97}$ Regardless of the result in any particular state, this is a conversation that should be occurring in state legislatures across the country.

These differences also argue in favor of considering a range of state approaches than include eliminating the use of eminent domain to build fossil fuel projects as well as prohibiting new fossil fuel projects outright. While a ban on all new fossil fuel projects is certainly an option, it may be more difficult to implement. While the legislature can target particular fossil fuel projects for prohibition, like the states that have already prohibited electric utilities from building new coal-fired power plants, further targets may not be as easy to choose. ${ }^{98}$ For instance, should state law

96. See, e.g., Serkin \& Vandenbergh, supra note 57 (discussing natural gas as a "bridge fuel"); Robert Walton, Xcel Minnesota Plans to Retire 2.4 GW of Coal, Critics say Natural Gas Has Too Big a Role in IRP, UTIL. Dive (July 3, 2019), https://www.utilitydive.com/news/xcel-minnesota-plans-to-retire-24-gw-of-coal-criticssay-natural-gas-has/558137/ [https://perma.cc/D4UP-82EH] (discussing disputed role of natural gas in Minnesota in connection with Xcel Energy's integrated resource plan for future energy needs filed with state regulators); Brad Plumer, As Coal Fades in the U.S., Natural Gas Becomes the Climate Battleground, N.Y. TimEs (June 26, 2019), https://www.nytimes.com/2019/06/26/climate/natural-gas-renewables-fight.html [https://perma.cc/FD6H-LSTW] (discussing debates over whether new natural gas plants are compatible with a zero carbon emission future).

97. Peter Behr, 100\% Renewable Grid Could Cost Trillions-Study, E\&E NEWS: $\quad$ ENERGYWIRE (July 1, 2019), https://www.eenews.net/energywire/2019/07/01/stories/1060678667 (discussing study showing high cost of moving to $100 \%$ renewable energy and suggesting instead that a combination of natural gas plus renewables in the shorter term would allow for development of new carbon reduction technologies); Wendy B. Jacobs \& Michael Craig, Carbon Capture and Sequestration, in Legal Pathways to DeEP DeCARBonization, supra note 3 , at 713, 715-17 (discussing ability of CCS to help achieve deep decarbonization in the United States); Walton, supra note 96 (discussing role of natural gas in energy transition); Jennifer Lu, California is Set to Go Carbon Free by 2045, Popular ScI. (Sept. 10, 2018), https://www.popsci.com/california-100-percent-renewable/ [https://perma.cc/MN3E-QP5E] (discussing role of CCS, nuclear energy, and technology development as important components of meeting California's carbon free mandate); Great Plains Inst., The Importance of Carbon Capture to Decarbonizing the ELECTRICITY SECTOR (2019).

98. See, e.g., North Dakota v. Heydinger, 825 F.3d 912, 922 (8th Cir. 2016) (striking down Minnesota law restricting out-of-state imports of power from new electric generating facilities that would increase state-wide carbon emissions on dormant Commerce Clause grounds but confirming validity of separate provision of the law that "prohibit[s] constructing within Minnesota a new large energy facility that would contribute to state-wide carbon emissions"); Lin Doan \& Jim Efstethiou, Jr., New York is Killing Off its Last Coal-Fired Power Plants, Bloomberg (May 9, 2019), 
ban all new natural gas plants, or only those not necessary to serve as a backup to renewable energy plants? How difficult will it be to craft a law that can easily distinguish between the two? Should the state legislature make that decision or delegate authority to the state's public utility commission?

With regard to fossil fuel pipelines, Governor Cuomo in New York has used his authority under the Clean Water Act in recent years to create roadblocks to new interstate natural gas pipelines through the state, but federal law governs the approval and use of eminent domain for these projects, so state authority is limited. ${ }^{99}$ While there is no federal law that expressly prohibits states from banning interstate oil pipelines outright, a state legislature might still pause before blocking the flow of petroleum to its citizens at a time when petroleum products provide over ninety percent of U.S. transportation energy. ${ }^{100}$

By contrast, it is a more modest, yet still significant, step to eliminate or create heightened scrutiny for the use of eminent domain for particular types of projects, so long as such a law applies to in-state and outof-state projects alike and thus does not violate the dormant Commerce Clause. ${ }^{101}$ Nevertheless, as a matter of policy, some would argue that eliminating eminent domain for oil pipelines-thus making those projects more difficult to build - will simply mean that more oil will travel by rail, leading to an increase in the potential for oil train explosions. While this argument has some appeal, transporting oil by rail is significantly more expensive than transporting it by pipeline, with the result being that oil becomes a less economically favored fuel as compared to more sustainable alternatives. ${ }^{102}$ This could serve to actually reduce the use of oil in the transportation sector rather than simply changing its

https://www.bloomberg.com/news/articles/2019-05-09/new-york-to-kill-state-s-last-coalplants-with-an-emissions-rule [https://perma.cc/6W8W-CPRW] (discussing new state rules that would prohibit existing coal-fired power plants from operating and prevent the construction of new plants); Andrew Topf, Oregon Becomes First US State to Ban CoalFired Power, Mining.com (Mar. 6, 2016), http://www.mining.com/oregon-becomesfirst-us-state-to-ban-coal-power/ [https://perma.cc/M3RJ-PB8H].

99. For more information on New York's use of the Clean Water Act to stop interstate natural gas pipelines, see Coleman \& Klass, supra note 54, at 728 n.302 (discussing litigation).

100. See Klass \& Meinhardt, supra note 31, at 947-48, 1026; Sources of Greenhouse Gas Emissions, supra note 12.

101. See, e.g., Felix Mormann, Market Segmentation vs. Subsidization: Clean Energy Credits and the Commerce Clause's Economic Wisdom, 93 WASH. L. REV. 1853 (2018) (discussing dormant Commerce Clause challenges to state energy laws).

102. See Rebecca Elliott \& Paul Ziobro, Oil Trains Make Comeback as Pipeline Bottleneck Worsens, WALL ST. J. (Jan. 31, 2019), https://www.wsj.com/articles/oil-trainsmake-comeback-as-pipeline-bottlenecks-worsen-11548930600 (reporting that transporting a barrel of oil from Canada to the Gulf Coast by rail costs $\$ 20$ as compared to $\$ 12.50$ to transport it by pipeline). 
mode of transportation, particularly if other provisions of the new clean energy laws are effective in electrifying the transportation sector. ${ }^{103}$ Moreover, it is not at all clear that the risk of rail accidents makes oil pipelines a more sustainable mode of transportation when environmental damage from significant oil pipeline leaks and spills is taken into account. ${ }^{104}$

One might ask why a state that wishes to restrict the use of eminent domain for fossil fuel projects should also expand the use of eminent domain for clean energy projects. Eminent domain is controversial, interferes with private property rights, and certainly is not politically popular. Perhaps states should eliminate eminent domain for fossil fuel projects without extending it for clean energy projects? Such an approach would have strong support from property rights advocates. However, extending eminent domain authority for at least some clean energy projects shows that a state is serious about a transition to clean energy. It also recognizes that a clean energy transition cannot occur solely by using property rights reform to stop fossil fuel projects. Policymakers should make a clear statement that private actors who build clean energy projects will be supported not solely through financial incentives and the work of new state committees and councils but also through property incentives. ${ }^{105}$

Such an approach also takes a bold stand against "not in my backyard" (NIMBY) tendencies that may gain steam if not tempered by a recognition that controversial energy projects will need to be built to

103. See, e.g., Coral Davenport, E.P.A. Says Pipeline Could Spur Emissions, N.Y. TIMES (Feb. 3, 2015), https://www.nytimes.com/2015/02/04/us/politics/epa-reviewof-keystone-pipeline-notes-potential-rise-in-greenhouse-gases.html [https://perma.cc/VZ9W-82AA] (reporting on a study by U.S. EPA during the Obama Administration concluding that Keystone XL Pipeline could increase U.S. emissions if oil prices dropped below a specific price by providing a less expensive transport method than rail to bring Canadian tar sands oil to the United States); Indigenous Envtl. Network v. U.S. Dep't of State, 347 F. Supp. 3d 561, 577 (D. Mont. 2018) (discussing EPA study and assessment that a drop in oil prices would impact whether oil would travel by rail in absence of pipeline), appeal dismissed, 2019 WL 2542756 (9th Cir. June 6, 2019).

104. See Klass, supra note 83, at 834-40, 887-96 (discussing benefits and drawbacks associated with transporting oil by rail and by pipeline); James Conca, Which is Safer for Transporting Crude Oil: Rail, Oil, Pipeline, or Boat?, ForBes (Oct. 11, 2018), https://www.forbes.com/sites/jamesconca/2018/10/11/which-is-safer-fortransporting-crude-oil-rail-truck-pipeline-or-boat/\#14158c4e7b23

[https://perma.cc/RP4Y-U5PJ].

105. See David Iaconangelo, N.Y.'s Plan to Fast-Track Renewables Could Get "Ugly," E\&E NEWS: ENERGYWIRE (Feb. 25, 2020), https://www.eenews.net/stories/1062441241[https://perma.cc/2UP2-Z27H] (reporting on potential backlash from New York rural communities to Governor Cuomo's plan to eliminate permitting and environmental review barriers to renewable energy projects). 
bring about an energy transition. ${ }^{106}$ Just "saying no" to large-scale energy projects is not a viable option. Indeed, if a state is serious about making transformational change in its energy sector, it should at least consider a tool-eminent domain - that was critical in bringing about earlier transformational changes in the United States, such as the creation of the interstate highway system, the railroad, and the current network of oil and natural gas pipelines and interstate electric transmission lines that currently support the nation's energy economy. ${ }^{107}$ Eminent domain played a significant role in building this infrastructure. Thus, its use as a policy tool should be part of the current legislative debates in states that embrace a major transition to clean energy. ${ }^{108}$

Following this approach raises the issue of which clean energy projects should be eligible for enhanced eminent domain authority. There are good arguments that eminent domain is not necessary for energy generation projects like wind farms, solar plants, and the like. Such projects are usually located within a single state, and land assembly is not always a major barrier. A project proposer can and should have to negotiate with landowners for easements and other necessary property interests, and the risk of holdouts is modest.

By contrast, long linear projects like interstate highways, interstate electric transmission lines, and interstate pipelines have a particular need for eminent domain authority because of the difficulty of assembling numerous contiguous parcels, which can encourage landowners to "hold

106. See id. (reporting on statements by experts and government officials recognizing that addressing climate change will require the rapid construction of new renewable energy projects).

107. See, e.g., History of the Federal Use of Eminent Domain, U.S. DeP'T JUSTICE (May 15, 2015), https://www.justice.gov/enrd/history-federal-use-eminentdomain [https://perma.cc/9SXB-TUDL] (discussing importance of federal eminent domain authority to "facilitate transportation, supply water, construct public buildings, and aid in defense readiness" as well as to "serve the needs of a growing population for more and updated modes of transportation"); U.S. GOV'T ACCOUNTABILITY OFF., GAO-07-28, Eminent Domain: Information About its Uses and EFFEcts on Property Owners AND COMMUNITIES IS LiMiTED (2006) (report to Congress prepared after Kelo decision to evaluate impact of eminent domain actions on communities and discussing range of uses for eminent domain); Eroll E. Meidinger, The Public Uses of Eminent Domain: History and Policy, 11 ENVTL. L. 1, 37-41 (1980) (discussing use of eminent domain for infrastructure projects in the United States, including the federal highway system, during the 20th century).

108. See Welton, supra note 9, at 1069-70 (new state carbon reduction mandates are "likely to require the replacement of significant infrastructure at substantial expense"); Emily Hammond \& Jim Rossi, Stranded Costs and Grid Decarbonization, 82 BROOK. L. REV. 645, 663-64 (2017) (stating that decarbonization "stands to be one of the most significant economic transformations the economy has experienced in the last century"). 
out" for above-market value. ${ }^{109}$ With regard to electric transmission lines needed to transmit clean energy, it is well documented that many states unnecessarily limit which types of companies can seek the permitting certificates needed to exercise eminent domain and sometimes do not consider interstate transmission lines proposed to transport electric energy to other states a "public use" under state law. ${ }^{110}$ Thus, if states take seriously the need to transition to clean energy, one policy approach is to create enhanced eminent domain authority for electric transmission lines designed to transmit clean energy, regardless of whether the party seeking to build the project is an electric utility or a merchant transmission line company. States can also revise their definitions of "public use" to make clear that lines designed to transport clean energy from, to, or through the state constitute a public use.

Integrating eminent domain law into climate policy has some less obvious benefits as well. State climate policy places a significant burden

109. See, e.g., United States v. Carmack, 329 U.S. 230, 236 (1946) ("The power of eminent domain is essential to a sovereign government. If the United States has determined its need for certain land for a public use that is within its federal sovereign powers, it must have the right to appropriate that land. Otherwise, the owner of the land, by refusing to sell it or by consenting to do so only at an unreasonably high price, is enabled to subordinate the constitutional powers of Congress to his personal will."); County of Wayne v. Hathcock, 684 N.W.2d 765, 781-82 (Mich. 2004) ("If a property owner between points A and B holds out-say, for example, by refusing to sell his land for any amount less than fifty times its appraised value - the construction of the railroad is halted unless and until the railroad accedes to the property owner's demands. And if the owners of adjoining properties receive word of the original property owner's windfall, they too will refuse to sell. The likelihood that property owners will engage in this tactic makes the acquisition of property for railroads, gas lines, highways, and other such 'instrumentalities of commerce' a logistical and practical nightmare."); Bell, supra note 24, at 531 ("Imagine that the land in the valley is owned by a number of private individuals. The government must now purchase for the reservoir all the valley parcels in the drainage basin; even one holdout in the middle of the planned reservoir can ruin the project . . . [and] strategic considerations may block the transaction.").

110. In 2011, the Arkansas Public Service Commission denied regulatory approval to a merchant transmission line company seeking to build an interstate transmission line to transport wind energy. The Commission stated that " $[t]$ he difficulty the $[$ Arkansas] Commission now faces is that the law governing public utilities was not drafted to comprehend changes in the utility industry such as this one-where a non-utility, private enterprise endeavors to fill a void in the transmission of renewable power that is much needed but for which the Commission is unable to afford regulatory oversight." In re Plains \& Eastern Clean Line LLC, Docket No. 10-041-U, Order No. 9 (Ark. Pub. Serv. Comm'n, Jan. 11, 2011). See also Miss. Power \& Light Co. v. Conerly, 460 So. 2d 107 (Miss. 1984) (no public use for electric transmission line where line would not serve in-state electricity customers); Jeffrey Tomich, Battle Reignites Over $\$ 2.5 B$ Midwest Transmission Line, E\&E NEws: ENERGYWIRE (Dec. 19, 2019), https://www.eenews.net/stories/1061847775 [https://perma.cc/4DCX-735P] (discussing legal challenges in multiple states to proposed Grain Belt Express merchant transmission line designed to transport wind energy to markets, including proposed legislation in Missouri to prohibit the use of eminent domain for the project); Carlton, supra note 86. 
on states to provide funding, new commissions and agencies, implementing regulations, and the like. This requires money, new staff, attention, and continued political support beyond the current state legislature and governor. Eminent domain law does not require those resources. Once it is extended or withdrawn, it sets the rules for private actors in the energy industry to build and not build according to policymakers' wishes. And eminent domain laws, like other property laws, are often fairly durable. A review of state eminent domain laws governing energy projects reveals that many of them remain on the books without amendment for many decades. It often takes a high-profile event, such as a controversial pipeline or the Kelo case, to spur legislators to action. This is why there has been minimal reform in terms of extending eminent domain authority for clean energy projects or withdrawing it from fossil fuel projects, with the exception of the temporary moratoria in Georgia and South Carolina. ${ }^{111}$ To date, state legislatures have not made changes to eminent domain law as part of their clean energy laws. In order for them to do so, they must first recognize the importance of eminent domain law as climate policy.

\section{Process Issues: Creating Statutory Presumptions in Eminent Domain Law}

Once a legislature determines that it will alter which types of energy projects may and may not exercise eminent domain authority, questions remain about the process for granting and denying that authority in any particular case. Most states currently have statutes that define entire categories of projects - like oil pipelines or utility-owned electric transmission lines-as a "public use" outright or, in the alternative, as a public use after receipt of a certificate of public convenience and necessity from the state public utility commission. Illinois, however, provides an alternate approach that may be useful in any statutory reform designed to utilize eminent domain as a component of state climate policy.

In 2007, the Illinois legislature enacted a new law designed to "limit the use of condemnation power to assist private development." 112 Unlike most other states that enacted post-Kelo reform laws, the Illinois law applied equally to energy projects. Under the new law, evidence that the regulatory commission:

has granted a certificate or otherwise made a finding of public convenience and necessity for an acquisition of property (or

111. See supra notes $80-81$ and accompanying text.

112. Enbridge Energy (Ill.) LLC v. Kuerth, 69 N.E.3d 287, 309 (Ill. App. Ct. 2016) (quoting Richard F. Friedman, Initial Procedures and Pleadings of the State and Other Condemning Bodies, in ILlinOIs EMInENT Domain PRACTICE $§ 2.1$ (IICLE 2013)). 
any right or interest in property) for private ownership or control ... to be used for utility purposes creates a rebuttable presumption that such acquisition of that property (or right or interest in property) is (i) primarily for the benefit, use, or enjoyment of the public and (ii) necessary for a public purpose. ${ }^{113}$

The Illinois Court of Appeals applied the new statute in a dispute over the use of eminent domain for an oil pipeline in $2016 .{ }^{114}$ It held that even though the statute creates a strong presumption that a pipeline possessing a certificate may exercise eminent domain, landowners or others challenging the pipeline have the opportunity to establish through an evidentiary hearing in court by clear and convincing evidence that the project was not "primarily for the benefit, use, or enjoyment of the public" or was not "necessary for a public purpose." 115

On appeal from a remand of an evidentiary hearing on those issues, the appellate court in 2018 found that project opponents failed to rebut the presumption of public use and public purpose because oil and natural gas are "essential to modern American life and must be transported from production facilities to refineries and ultimately to consumers." 116 The court also noted that eminent domain for oil pipelines is "well supported by historical custom" and the Illinois legislature "has determined that pipelines are in the public interest and that it is efficient for private companies, rather than the government, to construct and maintain those pipelines." 117

A state legislature enacting a clean energy law could modify the statutory rebuttable presumption used in Illinois to create a presumption in favor of projects designed to facilitate the use of clean energy and a presumption against projects that would facilitate the use of fossil energy. For instance, if an electric utility or merchant transmission line company obtained a certificate to build a transmission line designed to transport wind energy, an opponent might attempt to rebut the presumption by showing that the line was not located sufficiently close to the targeted wind farms to accomplish that objective. Likewise, an electric utility or gas company might rebut a presumption against the use of eminent domain for a new natural gas plant or pipeline by establishing through clear and convincing evidence that the plant was being co-located with

113. Id. (quoting 735 ILl. COMP. STAT. 30-5-5(c) (2007)).

114. Id. at $313-15$.

115. Id. at 310,314 . 2018).

116. Enbridge Energy (Ill.) LLC v. Kuerth, 99 N.E.3d 210, 218 (Ill. App. Ct.

117. Id. at 220 . 
new wind and solar energy, would incorporate CCS technologies, and was designed to operate only as a back-up when wind or solar energy was unavailable. ${ }^{118}$ In this way, instead of eminent domain being an "all or nothing" right based on the project category, a state could provide nuance through use of expert state commissions and rebuttable presumptions. Finally, states could adopt enhanced compensation for landowners or process-based reforms to reduce opposition to favored energy projects. ${ }^{119}$

\section{Constitutional Questions and the Possibility of Federal Reform}

An important question that arises with these proposals for eminent domain reform is whether there are any state or federal constitutional limits on state elimination of eminent domain authority for targeted projects. If drafted properly, these laws should be able to avoid such legal concerns. For instance, if a state were to distinguish between in state and out-of-state pipeline companies or distinguish between pipelines carrying product for in state versus out-of-state distribution, the industry could likely raise a legitimate dormant Commerce Clause challenge. The industry could argue that the law "discriminates against out-of-state goods or nonresident economic actors" without being "narrowly tailored" to "advance a legitimate local purpose." 120 Therefore, states should avoid making such distinctions. Changes to property law can also raise regulatory takings claims. Here, however, the policy would apply only to new fossil

118. See, e.g., Interview by David Spence with Jesse Jenkins, The Best Route to Net-Zero Emissions, ENERGYTRADOFFS (Feb. 21, 2019), https://www.energytradeoffs.com/2019/05/12/jesse_jenkins/ (discussing role of natural gas in a low carbon energy future).

119. For a discussion of these options, see Coleman \& Klass, supra note 54, at 730-38 (discussing enhanced compensation, expanded landowner rights for parcel acquisition, and improved community involvement).

120. Tenn. Wine \& Spirits Retailers Ass'n v. Thomas, 139 S. Ct. 2449, 2460-61 (2019) (invalidating Tennessee durational residency requirement for liquor store operators, reciting standards for dormant Commerce Clause review, and stating that "the proposition that the Commerce Clause by its own force restricts state protectionism is deeply rooted in our case law"). See also Rocky Mountain Farmers Union v. Corey, 913 F.3d 940, 944-45, 948-49 (9th Cir. 2019) (upholding California's Low Carbon Fuel Standard and rejecting arguments that it violated the dormant Commerce Clause); Energy \& Env't Legal Inst. v. Epel, 793 F.3d 1169, 1174 (10th Cir. 2015) (opinion by now-Justice Gorsuch holding that Colorado renewable energy mandate did not violate the dormant Commerce Clause in part because "all fossil fuel producers in the area served by the grid will be hurt equally and all renewable energy producers in the area will be helped equally"); Alexandra B. Klass \& Elizabeth Henley, Energy Policy, Extraterritoriality, and the Dormant Commerce Clause, 5 SAn Diego J. Climate \& ENERGY L. 127 (2013-14) (discussing dormant Commerce Clause analysis in the context of state energy policy). 
fuel projects, not existing ones, thus limiting arguments that the law interferes with any reasonable, investment-backed expectations. ${ }^{121}$

Finally, state action in this area can serve as a template for Congress if, in future years, it wishes to enact federal climate policy. Congress could choose to create federal eminent domain authority for interstate electric transmission lines proposed to transmit wind and solar energy that meet requirements set by FERC or another federal agency, as was done for interstate natural gas pipelines in the 1940s. ${ }^{122}$ At the same time, Congress could eliminate eminent domain authority for interstate natural gas pipelines through amendments to the Natural Gas Act if, in the future, it determines it is in the national interest to phase out the continued use of natural gas for electricity, heating, or other uses. ${ }^{123}$ Such policy changes at the federal level are unlikely in the short term, although an increasing number of bills are making their way through both the U.S. House of Representatives and the U.S. Senate. ${ }^{124}$ But state experimentation now can open up a broader range of policy tools, including property law, as an increasing number of lawmakers embrace a clean energy transition.

\section{CONCLUSION}

A growing number of states have enacted aggressive policies to combat climate change and more are virtually certain to follow suit. It is also likely that Congress will eventually adopt climate policies in one form or another to encourage a shift away from fossil fuel energy and toward carbon-free energy. As lawmakers consider the components of such policies, they should not overlook the importance of property law in general and eminent domain law in particular. It will be virtually impos-

121. This proposal thus differs significantly from the scenario Professors Christopher Serkin and Michael Vandenbergh raised in a 2018 article on future regulations to restrict or eliminate the use of existing natural gas generation and transmission investments to address climate change. That article suggested a "prospective grandfathering" approach to allow the elimination of natural gas without triggering regulatory takings concerns. See Serkin \& Vandenbergh, supra note 57.

122. See supra notes 31-34 and accompanying text.

123. The federal courts have begun to place some requirements on FERC to evaluate the GHG emissions of proposed interstate natural gas pipelines and FERC on its own could subject such pipelines to greater scrutiny as well. See Coleman \& Klass, supra note 54, at 684-85; KLASS \& WISEMAN, supra note 27, at 32 (discussing litigation over FERC evaluation of GHG emissions for natural gas pipeline certificates). See also Sierra Club v. Fed. Energy Regulatory Comm'n, 867 F.3d 1357 (D.C. Cir. 2017) (holding that FERC violated National Environmental Policy Act by failing to adequately evaluate downstream GHG emissions associated with proposed interstate natural gas pipeline that would bring natural gas to Florida for electricity generation in natural gas plants in that state).

124. See supra note 4 (discussing proposed federal legislation). 
sible to meet the current and future climate mandates and goals without a massive shift in the physical infrastructure used to generate, transmit, and use energy. This requires building new clean energy projects and imposing barriers on building new fossil fuel projects. Throughout U.S. history, states and Congress have used eminent domain law as an incentive or disincentive for private actors in the energy sector. It would be shortsighted for lawmakers today to overlook this policy tool. Instead, they should consider the role of eminent domain law in climate policy and use it, as appropriate, for both clean energy projects and fossil fuel projects. 